\title{
Reclamation of Potholes by Utilisation of Plastic
}

\author{
Nidhi Saji ${ }^{1}$, Isha P. Khedikar ${ }^{2}$, Seema Diwan ${ }^{3}$ \\ ${ }^{1} \mathrm{M}$. Tech Scholar, Transportation Engineering, Department of Civil Engineering GHRCE, Nagpur, Maharashtra, India \\ ${ }^{2}$ Assistant Professor, Department of Civil Engineering GHRCE, Nagpur, Maharashtra, India Assistant Engineer, \\ ${ }^{3}$ Public Work Department, Raipur, Maharashtra, India
}

\begin{abstract}
Article Info

Volume 8, Issue 4

Page Number : 592-597

Publication Issue

July-August-2021

Article History

Accepted : 07 Aug 2021

Published : 14 Aug 2021

The rate of accidents caused by potholes is increasing day by day. So, potholes must be repaired as soon as possible. This paper aims to repair potholes by using plastic. The introduction of plastic in bitumen modifies the characteristic of bitumen. Tests were done on aggregate and bitumen to check their quality. Marshall Test on bitumen were done on different percentage of bitumen and plastic. From the result it was observed that as the percentage of plastic is increased the stability value of Marshall test is also increased.

Keywords : Aggregate, Bitumen, Bitumen, Plastic, Potholes
\end{abstract}

\section{INTRODUCTION}

As India is the developing country. India is having several bad roads wheather it is cities or villages potholes are common in both rural \& urban area. Crores of rupees are paid by road agencies to repair pothole. It also requires large amount of time, labours and human efforts to repair potholes. (Nachivanekar et al.,2019)

India is the country where plastic materials are mostly used in road construction (Sasidharan et.al 2019) .By use of plastic to repair potholes the lifespan of road increases(Nachivanekar, et.al 2019)). Potholes not only cause harm to vehicles but because of potholes serious accidents are also happened. Because of heavy traffic load, water pressure elaborates in the wet materials which cause failure of material. Deficient in road maintenance also results in elaboration of surface crack, this crack permits the water to step into the layers during rainfall. (Naveen et.al, 2018)

Potholes on the surface of asphalt pavements significantly reduce pavement condition, and potentially impair traffic safety. Potholes on the surface of asphalt pavements significantly reduce pavement condition, and potentially impair traffic safety. Potholes on the surface of asphalt pavements significantly reduce pavement condition, and potentially impair traffic safety Different materials are used to repair potholes present in the pavement (Ballari,2019). Studies have shown that plastics may be used with bitumen so that it can result in better performance of pavement and also gives strength and resistance to deformation. (Mishra et.al 2016)

Plastics are generally used in every work due to their different varieties and characteristics. Plastics are inexpensive so they are used widely 
(Deshmukh,2018). Disposal of plastic waste is common and serious problem. Disposal of plastic increase risk to person health and it also pollute the environment. Hence, it is needed to recycle the plastic.(Yadav,2017)

\section{MATERIALS AND METHOD}

\subsection{Study Area}

Only Two Potholes were found at Naya Raipur from Muktangan Garden to Mantralaya Road the potholes are shown in Figure 2.1 and dimensions of potholes are shown in Table 2.1

Table 2.1 : Dimensions of Potholes

\begin{tabular}{|l|l|l|l|l|}
\hline Sr.no. & $\begin{array}{l}\text { Length } \\
(\mathrm{cm})\end{array}$ & $\begin{array}{l}\text { Depth } \\
(\mathrm{cm})\end{array}$ & $\begin{array}{l}\text { Area } \\
\left(\mathrm{cm}^{2}\right)\end{array}$ & $\begin{array}{l}\text { Volume } \\
\left(\mathrm{cm}^{3}\right)\end{array}$ \\
\hline $\begin{array}{l}\text { Pothole } \\
1\end{array}$ & 52 & 8.89 & 2109.12 & 18750 \\
\hline $\begin{array}{l}\text { Pothole } \\
2\end{array}$ & 60 & 10.16 & 2826 & 28712 \\
\hline
\end{tabular}

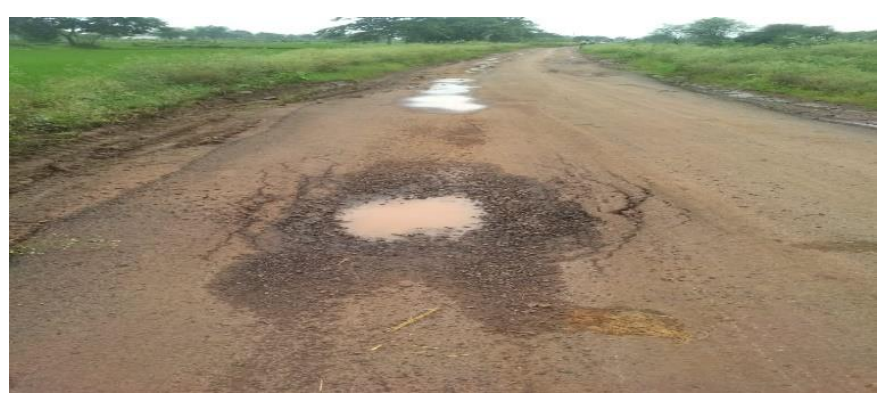

Figure 2.1 : Identified potholes

For repairing of potholes test were done on aggregate and bitumen.

\subsection{Test Done on Aggregate}

The Aggregate used were of size $20 \mathrm{~mm}$ and $10 \mathrm{~mm}$.

\subsubsection{Impact Value Test}

This test measures the resistance to sudden shock that is caused due to application of loads. This test is done on aggregate as per I.S. Code IS: 2386 Part 4 . This test is used to determine toughness of aggregate. Impact Test is shown in Figure 2.2
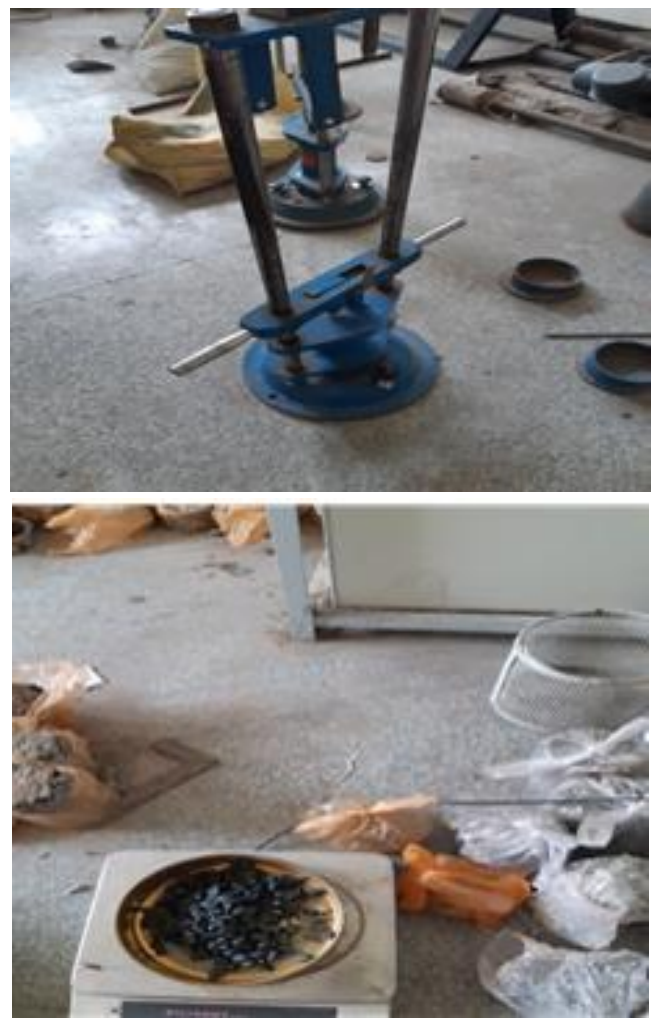

Figure 2.2 : Aggregate Impact Value Test

\subsubsection{Los Angeles Test}

This test is used to check the quality of aggregate. This test is used to determine hardness of aggregate. Los Angeles Abrasion Test is shown in Figure 2.3. This test is done on aggregate as per I.S. Code IS: 2386 Part 4.

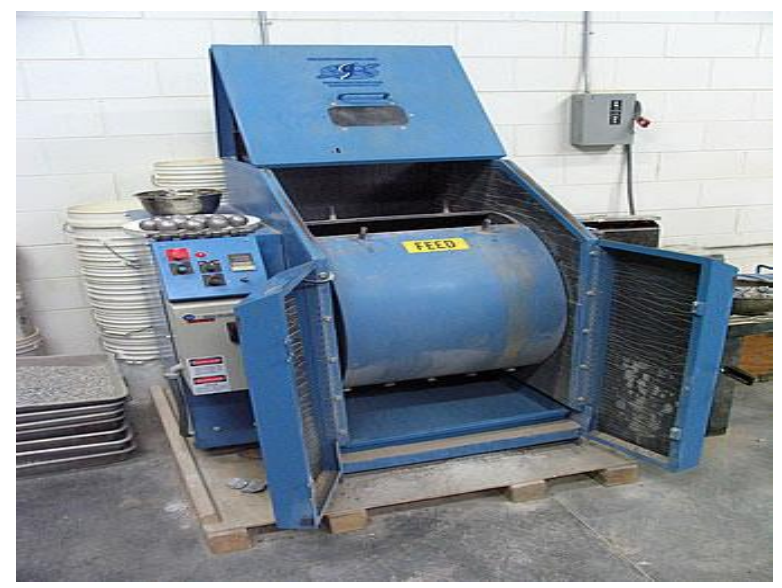

Figure 2.3 : Los Angeles Abrasion Test

\subsubsection{Moisture Content Test}

This test is done on aggregate as per I.S. Code IS: 2386 Part 3. This test in done to determine water content of aggregate. Moisture content Test is shown in Figure 2.4 


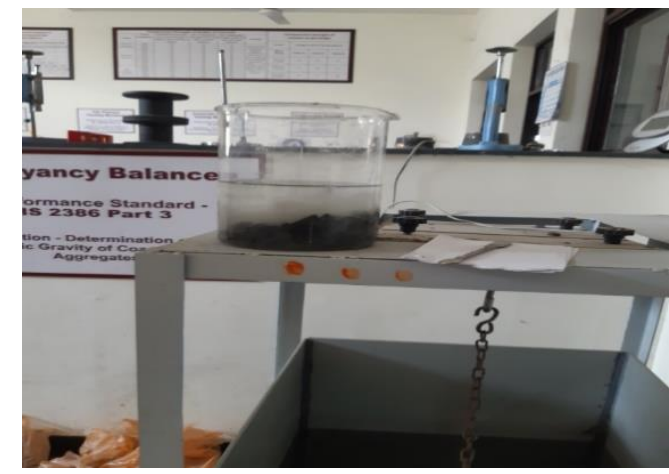

Figure 2.4 : Moisture Content Test

Table 2.2 - Results of Tests Performed on Aggregate

\begin{tabular}{|l|l|l|l|}
\hline S.no. & Test & Result & IS code \\
\hline 1. & Impact Test & $11.4 \%$ & IS 2386 Part4 \\
\hline 2. & $\begin{array}{l}\text { Los Angeles } \\
\text { Abrasion }\end{array}$ & $13 \%$ & IS 2386 Part4 \\
\hline 3. & $\begin{array}{l}\text { Moisture } \\
\text { Content }\end{array}$ & $1.2 \%$ & IS 2386 Part3 \\
\hline
\end{tabular}

Table 2.2 shows Results of Tests Performed on

$$
\text { Aggregate. }
$$

\subsection{Test on Bitumen-}

Bitumen of grade V30, 5\% Plastic was used

\subsubsection{Penetration Test}

This test is done to determine the hardness of bitumen by measuring its depth in millimetre to which a needle will penetrate vertically in five seconds. This test is done as per IS 1203.

\subsubsection{Specific Gravity Test}

This test is done as per IS 1202. This test is done to determine the Specific Gravity of bitumen.

Table 2.3- Results of Tests Performed on Bitumen-

\begin{tabular}{|l|l|l|l|}
\hline S.no & Test & Result & IS Code \\
\hline 1. & $\begin{array}{l}\text { Penetration } \\
\text { Test }\end{array}$ & $69 \mathrm{~mm}$ & IS1203 \\
\hline 2. & $\begin{array}{l}\text { Specific } \\
\text { Gravity Test }\end{array}$ & 1.015 & IS 1202 \\
\hline
\end{tabular}

Table 2.3 shows Results of Tests Performed on Bitumen

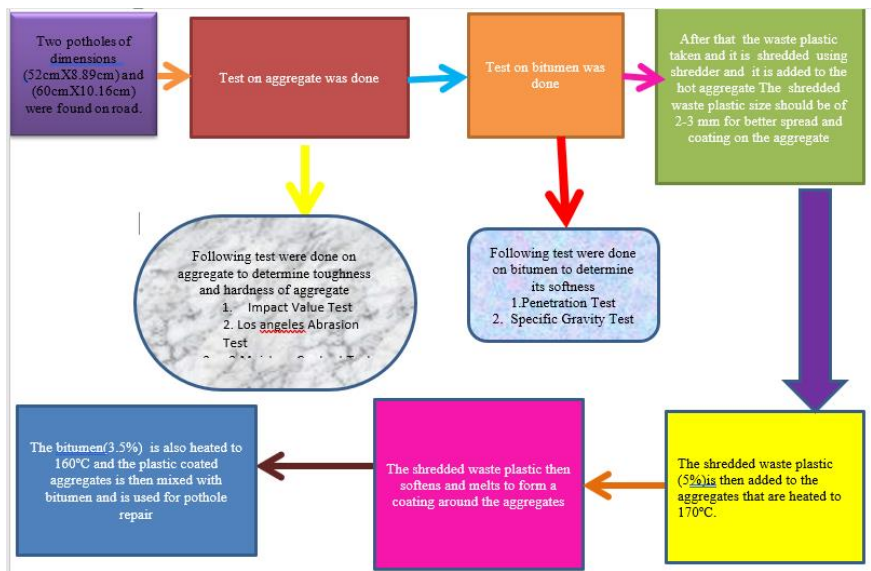

Figure 2.5 - Flow chart of Pothole Repair Process Steps to repair potholes-

1. Firstly the waste plastic is cut into pieces using shredder and then it is put in warm aggregate.

2. The plastic piece size should be of $2-3 \mathrm{~mm}$ for better spread of plastic so that the plastic get coated on the aggregate.

3. After that the pieces of plastic is put in the aggregates and are heated at $170 \circ \mathrm{C}$.

4. Now the plastic piece gets soften and it melt to form coat on all sides of aggregates.

5. After that bitumen is heated at $160^{\circ} \mathrm{C}$ and the plastic coated aggregates are added with the bitumen and they are used to repair pothole.

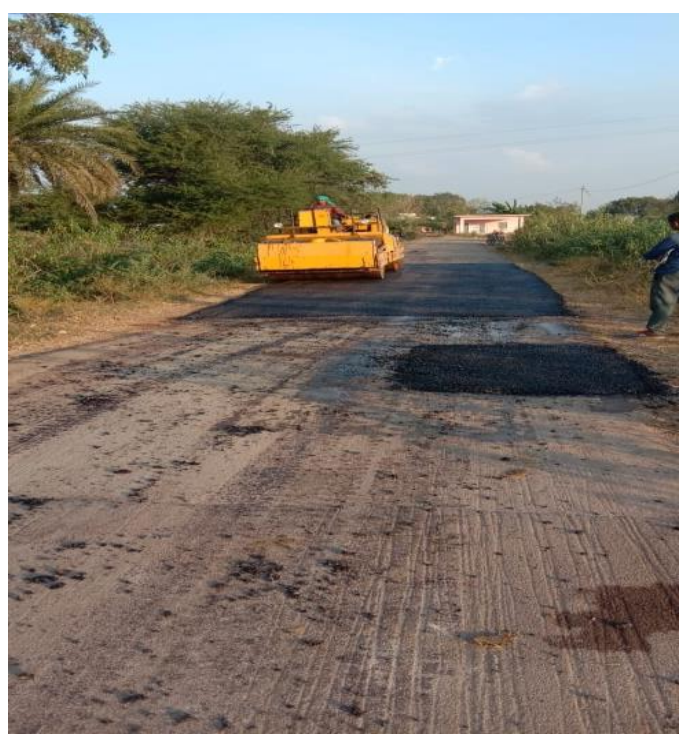

Fig 2.6 Repaired Potholes

\section{Marshall Test}

Marshall Test was done to check the stability of material .Marshall Test is done as per ASTM D6927 06. This test was done on $4 \%, 4.5 \%, 5 \%, 5.5 \%$ and $6 \%$ of bitumen and $5 \%, 6 \%, 7 \%, 8 \%$ and $9 \%$ of plastic. Marshall test apparatus is shown in fig 2.6 


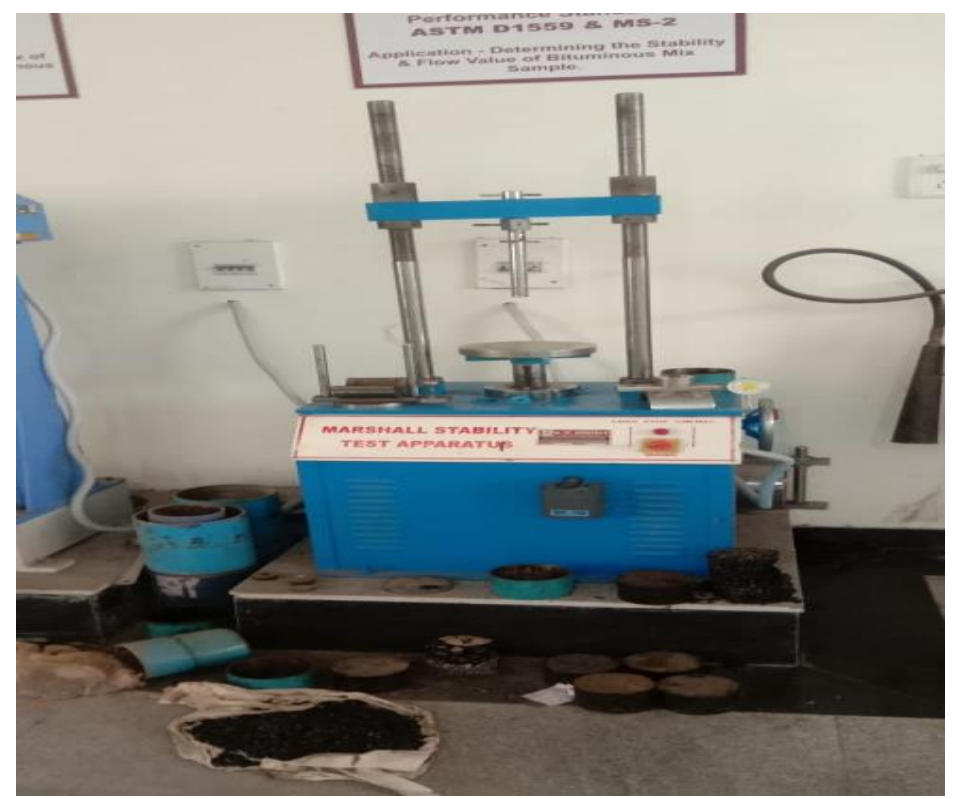

Fig 3.1 Marshall Test Apparatus

Table 3.1- Result of Marshall stability test for different \% of bitumen

\begin{tabular}{|l|l|l|l|l|l|l|l|}
\hline S.NO & $\begin{array}{l}\text { Bitumen } \\
\text { Content } \\
\text { (Percentag } \\
\text { e) }\end{array}$ & $\begin{array}{l}\text { Specific gravity } \\
\text { maximum } \\
\text { (Theoretical) }\end{array}$ & $\begin{array}{l}\text { Bulk } \\
\text { specific } \\
\text { gravity }\end{array}$ & $\begin{array}{l}\text { \% of } \\
\text { Air } \\
\text { voids }\end{array}$ & $\begin{array}{l}\text { Voids \% filled } \\
\text { with bitumen }\end{array}$ & $\begin{array}{l}\text { Test Value of } \\
\text { Marshall } \\
\text { Stability Test } \\
(\mathrm{Kg})\end{array}$ & $\begin{array}{l}\text { Flow Test } \\
\text { Value } \\
(\mathrm{mm})\end{array}$ \\
\hline 1. & 4 & 2.34 & 2.222 & 5.43 & 71.70 & 1670 & 6.82 \\
\hline 2. & 4.5 & 2.37 & 2.268 & 4.69 & 73.62 & 1842 & 4.22 \\
\hline 3. & 5 & 2.41 & 2.308 & 4.02 & 75.4 & 2014 & 3.25 \\
\hline 4. & 5.5 & 2.40 & 2.298 & 3.82 & 77.8 & 1899 & 3.4 \\
\hline 5. & 6 & 2.38 & 2.318 & 3.77 & 78.88 & 1784 & 4.10 \\
\hline
\end{tabular}

Table 3.1 Shows that Marshall Stability value of different percentage of bitumen and from the table it can be seen that the stability value of $5 \%$ bitumen is maximum.

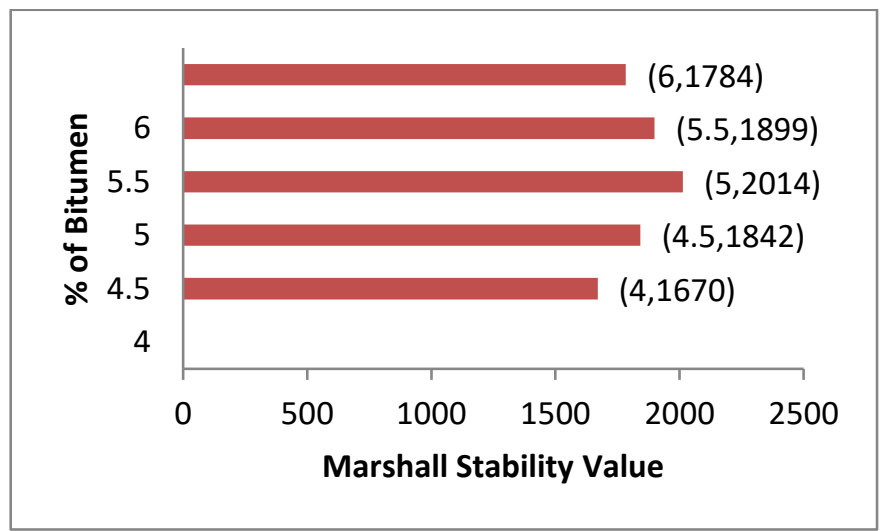

Fig 3.2 - Different percentage of Bitumen and Marshall Stability Value
From figure 3. 2. it can be seen that stability value of $5 \%$ bitumen stability value is maximum as compared to $4 \%, 4.5 \%, 5.5 \%$ and $6 \%$. 


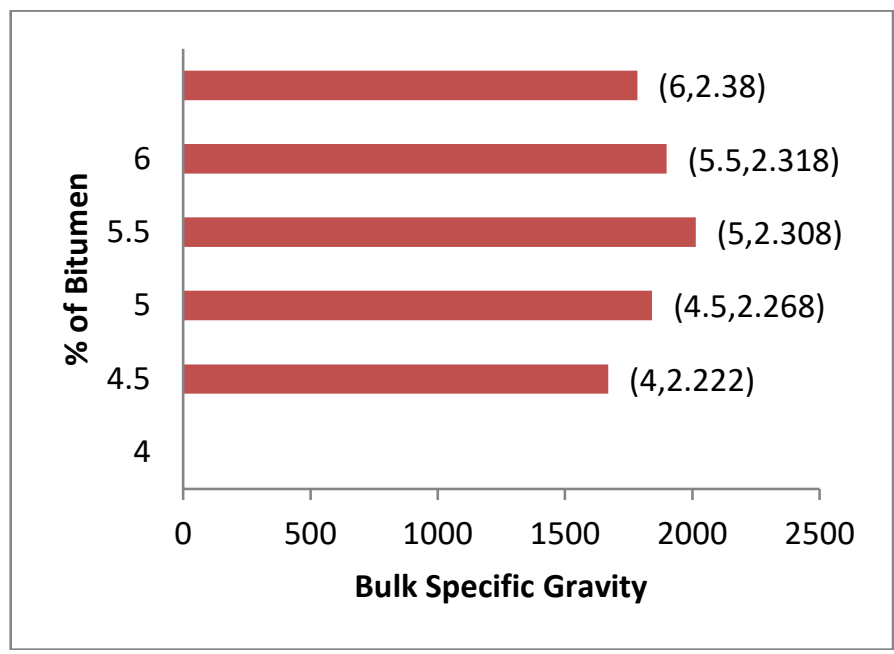

Fig 3.3 Different percentage of Bitumen and Bulk specific gravity

The 3.3 figure shows that when $6 \%$ bitumen has maximum bulk specific gravity as compared to $4 \%, 4.5 \%, 5.5 \%$ and $5 \%$.

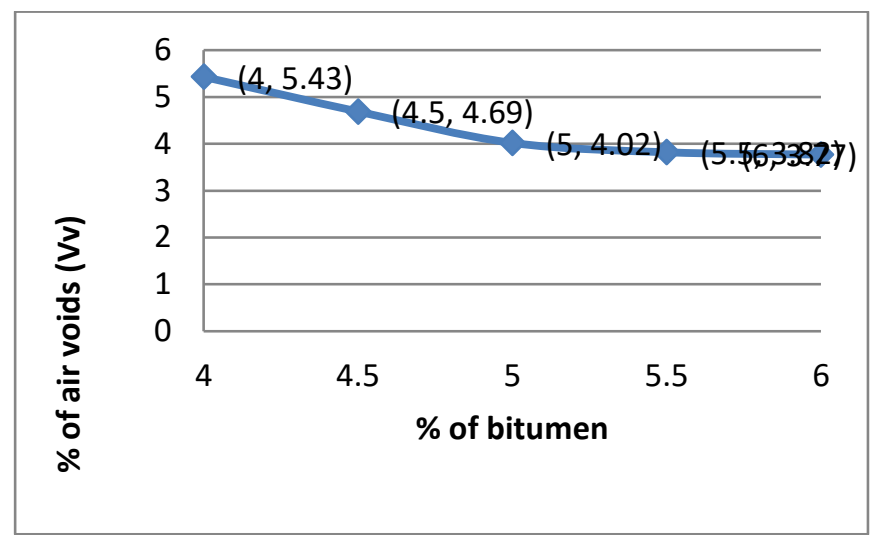

Fig 3.4 - Different \% of Bitumen and \% of Air voids From figure 3.4 it can be seen that that $4 \%$ bitumen has maximum value as compared to $4.5 \%, 5 \%, 5.5 \%$ and $6 \%$

Table 3.2 - Result of Marshall Stability test for Different percentage of plastic

\begin{tabular}{|l|l|l|l|l|l|l|l|}
\hline S.No. & $\begin{array}{l}\text { percentage } \\
\text { of plastic }\end{array}$ & $\begin{array}{l}\text { specific } \\
\text { gravity } \\
\text { maximum } \\
\text { (Theoretical) }\end{array}$ & $\begin{array}{l}\text { Bulk } \\
\text { specific } \\
\text { gravity }\end{array}$ & $\begin{array}{l}\text { \% of Air } \\
\text { voids }(\mathrm{Vv})\end{array}$ & $\begin{array}{l}\text { voids \% } \\
\text { that is } \\
\text { filled with } \\
\text { bitumen } \\
\text { (VFB) }\end{array}$ & $\begin{array}{l}\text { Test } \\
\text { Value of } \\
\text { Marshall } \\
\text { Stability } \\
\text { Test (Kg) }\end{array}$ & $\begin{array}{l}\text { Flow } \\
\text { TestV } \\
\text { alue } \\
(\mathrm{mm})\end{array}$ \\
\hline 1 & 5 & 2.44 & 2.29 & 4.50 & 74.5 & 2175 & 3.2 \\
\hline 2 & 6 & 2.47 & 2.34 & 4.42 & 77.13 & 2277 & 3.18 \\
\hline 3 & 7 & 2.45 & 2.35 & 4.34 & 79.76 & 2380 & 3.16 \\
\hline 4 & 8 & 2.43 & 23.3 & 4.26 & 82.93 & 2575 & 2.8 \\
\hline 5 & 9 & 2.41 & 2.3 & 4.18 & 85.02 & 2770 & 2.3 \\
\hline
\end{tabular}

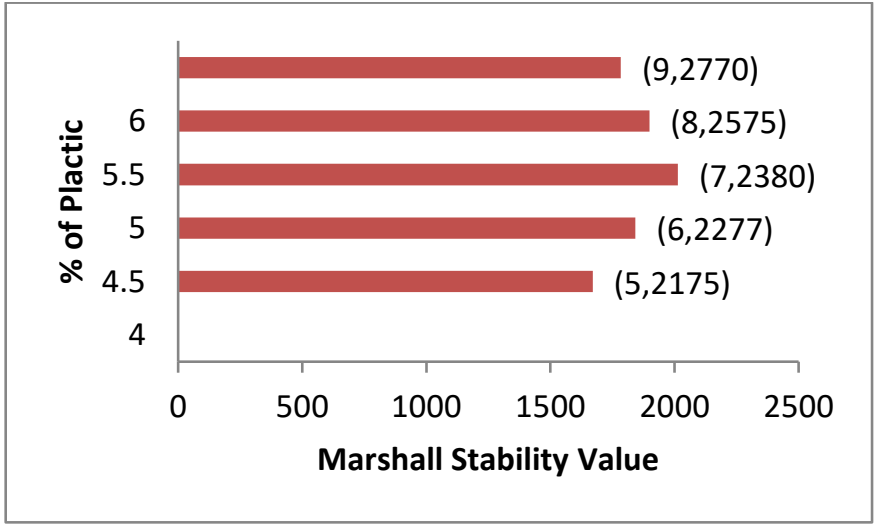

Fig 3.5-Different percentage of Waste Plastic vs. Marshall Stability Value
From figure 3.5 it can be seen that as the percentage of plastic is increased the stability value also increases. Hence $9 \%$ plastic has maximum stability value.

\section{III.CONCLUSION}

Potholes have been repaired by using plastic. It can be concluded that the stability of potholes filled with plastic is more as compared to bitumen. The potholes that are filled with plastics provides more strength and durability. Marshall stability test was also done on different percentage of plastic and bitumen and it 
can be concluded that as the percent of plastic increases the stability value also increases.

\section{REFERENCES}

[1]. Amina N S, 2019 ,"Pothole Reclamation using Different Pavement Mixes"Volume8, Issue 6

[2]. Manu Sasidharan , 2019 Using waste plastics in road construction

[3]. Prof. Amit Patil , 2018 "REVIEW PAPER OF DESIGN AND FABRICATION OF LIQUID PLASTIC POTHOLE REPAIRING MACHINE" Volume 3, Issue 10

[4]. Mihai Marasteanu ,2018 "Pothole Prevention and Innovative Repair “

[5]. Sainz, 2016 "Pothole Patching: "A Review on Materials and Methods", Bradley University, Peoria, IL 61625

[6]. Dax Patel,2018 “ Repair of Road Distress and Potholes with using Organosilane Based Technologies" Volume: 05 Issue: 02.

[7]. N.Naveen, 2018 "A Study on Potholes and Its Effects on Vehicular Traffic" Volume 6, Issue 1.

[8]. Gaurav Singh Parihar,2017 "STUDY ON POTHOLE FILLING METHODS AND TRUCKS." Volume: 07 Issue: 01

[9]. Amit Gawande,2019 An overview on waste plastic utilization in asphalting of roads

[10].Manoj Sasidharan ,2019 Using waste plastics in road construction

\section{Cite this article as :}

Nidhi Saji, Isha P. Khedikar, Seema Diwan, "Reclamation of Potholes by Utilisation of Plastic", International Journal of Scientific Research in Science and Technology (IJSRST), Online ISSN : 2395-602X, Print ISSN : 2395-6011, Volume 8 Issue 4, pp. 592-597, July-August 2021. Available at doi $\quad$ : https://doi.org/10.32628/IJSRST218484

Journal URL : https://ijsrst.com/IJSRST218484 